\title{
US military tightens rules on DNA records
}

Washington. The US Department of Defense (DoD) has agreed to modify the rules governing the use of the DNA records it keeps on military personnel, in response to increasing public concern that the records could be misused.

The move comes as two US Marines Lance Corporal John Mayfield and Corporal Joseph Vlacovsky - are due to be courtmartialled in Hawaii next week for refusing to contribute a DNA sample to what is believed to be the world's largest gene bank (see Nature 379, 385; 1996).

The DoD, which says it has built up its DNA records solely to aid the identification of troops killed in battle, now says that individuals can ask for their own record to be destroyed when they leave military service.

It also promises to destroy all such records itself after 50 years, rather than 75 years as it had previously promised, and has placed tight restrictions on the circumstances in which the information can be used for purposes other than identification of remains. But it still plans to continue the compulsory collection of DNA samples from soldiers and support personnel.

Eric Seitz, a civil rights lawyer representing the two Marines due to be courtmartialled next week, claims that the DoD is

\section{Court allows fossil fraudster to return}

New Delhi. A move by Panjab University in Chandigarh, India, to get rid of its controversial geologist, Viswa Jit Gupta, has backfired, causing dismay in the academic community and considerable embarrassment to authorities. Only three days after his offer to leave "voluntarily" was accepted by the university senate last month and he was allowed to retire, Gupta, who had been accused of faking Himalayan fossils (see Nature 369, 698; 1994), was reinstated by order of the Punjab and Haryana high court.

The judges overturned the senate decision on the grounds that Gupta had written a second letter withdrawing his resignation. The court therefore permitted Gupta to return to his job. Ironically, one result of this unexpected development is that the fossil case has ceased to be a domestic university affair and has moved to the courtroom.

The recent events began soon after Gupta had learnt that the university had called a special meeting of its senate on 17 March on the orders of India's vice-president, K. R. Narayanan, who is also chancellor of the university. Suspecting that the meeting was planned to dismiss him, Gupta asked on 1 March for voluntary retirement, and demanded that the meeting be cancelled. When the vice-chancellor, T. $\mathrm{N}$. Kapur, insisted on holding the meeting, Gupta sought the court's protection against any action by the senate, and sent the university another letter, withdrawing his earlier letter of resignation.

The court subsequently issued an order restraining the university from inflicting any "further punishment" on Gupta. As a result, the subsequent senate meeting could not take any action against him. Its only course of action was to accept his application for voluntary retirement and reject his second letter withdrawing his resignation. But Gupta appealed to the court again, arguing that the senate acted wrongly in rejecting his second letter - and won.

The fossil fraud was brought to the notice of the scientific community seven years ago by John Talent of Australia (see Nature 338, 613; 1989), but the Panjab University took nearly five years to declare Gupta guilty of misconduct. Even then, he received only mild punishment: his annual salary increments were stopped, but he continued to teach students, while his co-workers who had helped to expose the fraud were harassed by Gupta and his supporters in the senate (see Nature 378, 227; 1995).

Embarrassed by Gupta's continued presence on the university payroll, as well as criticism in both the national and international press, Narayanan had called the senate meeting to "take steps to restore the fair name of the university". But the course of action taken by the senate, far from penalizing Gupta, have now turned out to his advantage.

K. S. Jayaraman
Washington. The US National Aeronautics and Space Administration (NASA) inaugurated its new line of Medium-class Explorer (MIDEX) missions for space physics and astrophysics last week with the selection of two spacecraft to be

Charles Bennett of NASA's Goddard Space Flight Center in Maryland leads the Microwave Anisotropy Probe (MAP) project, to study the cosmic microwave background to help understanding of large-scale structure in the Universe. The Imager for Magnetopause-to-Aurora Global Exploration (IMAGE), led by James Burch of the Southwest Research Institute in San Antonio, Texas, will image the interaction of the Earth's magnetosphere with the solar wind.

The order of launch and exact launch dates are still to be decided. Both missions will receive money for developlaunched in 1999 and 2000. concerned that by not taking action over Mayfield and Vlacovksy, it would be "setting a precedent" that would encourage others to refuse to give the blood and tissue samples to the bank.

At a press conference in Washington last week, Mayfield and Vlacovsky said they had been unaware of the issues surrounding DNA testing when first asked to provide the samples. But they became suspicious when the DoD was unable to answer their questions about how the samples would be used.

Under a directive from Stephen Joseph, assistant secretary for health at DoD, DNA samples will now be used for purposes other than identifying remains only if the donor gives consent, or if the specimen is needed for the investigation of a serious crime.

Nevertheless, Wendy McGoodwin, director of the Council for Responsible Genetics (CRG), a lobby group which is supporting the Marines in a civil court action against DoD, dismisses the new directive as little more than window-dressing.

"We don't consider this to be a substantial alteration to the policy," says McGoodwin. The CRG is concerned that the one million records already contained in the DNA bank might eventually be used to support "genetic discrimination" inside and outside the military.

Seitz says that he welcomes the changes in the directive, while insisting that the civil action against the DoD will continue. But the Department of Defense itself hopes that its concessions will not only stifle the court challenge to its actions but also calm public concern about potential misuse of the gene bank.

Colin Macilwain

\section{NASA unveils astrophysics missions}

ment studies, with the final go-ahead for the first mission expected in about a year. Development costs for MIDEX missions are capped at $\$ 70$ million, not counting the launch vehicle, mission operations and data analysis.

The agency's 'New Millennium' programme, planned to develop advanced space technology, announced another flight project last week to test a new kind of Earth science sensor in orbit. The Advanced Land Imager instrument, to be built by a team led by the Massachusetts Institute of Technology's Lincoln Laboratory, will be sensitive in visible and short-wave infrared wavelengths.

The device is meant to improve on existing Landsat spectrometers in nearly every way - higher resolution, lower mass and lower cost. The test mission's overall cost, including launch, is being capped at $\$ 90$ million. Tony Reichhardt 